\section{Molecular Characterization of ESBL and Carbapenenemase Producing Salmonella spp. Isolated from Chicken and its Public Health Importance}

\author{
Mona Kadry, Sara Mohamed Nader*, Esraa A. Elshafiee and Zeinab S. Ahmed \\ Department of Zoonoses, Faculty of Veterinary Medicine, Cairo University, Cairo, Egypt.
}

Article Information
Received 16 July 2020
Revised 11 September 2020
Accepted 28 September 2020
Available online 08 October 2021
Authors' Contribution
MK, SMN, EAE and ZSA presented
the concept. MK and SMN wrote the
manuscript. ZSA prepared the
samples and applied bacteriological
examination and PCR assay. EAE
helped in laboratory work
Key words
Chicken meat, Salmonellae, ESBL,
Carbapenem, Egypt

A B S T RA C T

Antimicrobial resistance has become one of the most severe worldwide dangers to human and veterinary Medicine. $\beta$-lactam resistant Salmonellae are of great concern as they are becoming multi-drug resistant. This study describes the role of chicken in harboring and environmental spread of ESBL and carbapenemase - producing Salmonella spp, which could pose a potential hazard to human and animal health. A total of 334 chicken meat samples, 197 eggshells and 160 human stool specimens were included in this study. The presence of salmonellae spp. was examined using bacteriological isolation and serological identification. PCR amplification of the ESBL and carbapenemase-encoding genes was performed. The bacteriological examination of the samples showed that 6 Salmonella strains $[S$. Typhimurium (3), $S$. enteritidis (2) and $S$. Infantis (1)] were isolated from chicken meat and eggshell surface samples. In human, it was found that 6 salmonella strains ( $S$. Typhimurium, $S$. Enteritidis, $S$. Infantis, $S$. Virchow, $S$. Haifa, $S$. Kentucky) were isolated. The results of multiplex PCR showed that ESBL-producing salmonellae and Carbapenemresistant salmonellae occurred in four strains from chicken meat samples while not from egg, also in human five strains carried the $\beta$-lactamase-producing genes while no strain was positive to carbapenemases. The detection of ESBL and carbapenemase- producing salmonellae from chicken in Egypt is confirmed and represents a major public health problem.

\section{INTRODUCTION}

A ntibiotics are used as veterinary and human medicines for treatment, control and prevention of infectious diseases. However, their recurrent use can have unexpected adverse effects, including the development of antibiotic resistance which is the one of the greatest challenges in modern medicine (Doi et al., 2017). The prevalence of multidrug resistant organisms, a major threat to public health, continues to rise globally and is associated with significant morbidity and mortality (Logan and Weinstein, 2017). These trends are highlighted in Enterobacteriaceae, a family of gram-negative bacteria responsible for a variety of infections acquired from the community and the health care.

Salmonella is the most important foodborne pathogen which mostly found in poultry and egg. The majority of Salmonella infections cause self-limiting diarrhea and do not require antimicrobial treatment. However, in certain cases, Salmonella may lead to some complication, especially when it spread via blood stream. In such cases, fluoroquinolones and cephalosporins are the drugs of

\footnotetext{
Corresponding author: Dr.saranader@yahoo.com 0030-9923/2021/0006-2289 \$9.00/0

Copyright 2021 Zoological Society of Pakistan
}

choices (Miriagou et al., 2004). Resistance to these agents would compromise the efficacy of empiric treatment of suspected Gram-negative infections and limit the therapeutic options for their definitive treatment as well (Doi et al., 2017).

Many animal species, in particular chickens are potential reservoirs for this bacterium (Sanchez et al., 2002). Humans can get the infection through the food chain (Majowicz et al., 2010).

Today, treatment of bacterial infections in human and animals is facing several problems due to increased antimicrobial resistance (AMR) in bacteria against the most of the antibacterial agents. One of the most important AMR mechanisms in Enterobacteriaceae family is the production of extended-spectrum $\beta$-lactamase (ESBL) and metallo $\beta$-lactamases (MBLs) enzymes (carbapenem -resistant) (Lee and Ko, 2012).

According to Ambler classification, ESBL is divided into four main groups from A to D (Jacoby and MunozPrice, 2005). ESBL enzymes TEM, SHV, and CTX-M from Group A have been widely reported to be produced by bacteria. These enzymes can hydrolyze ampicillin, carbenicillin, oxacillin, and an extended spectrum of cephalosporins such as ceftazidime and cefotaxime (Paterson and Bonomo, 2005).

Infections due to ESBL-producing Enterobacteriaceae 
are concerned for many reasons including increased hospital costs, length of stay, and mortality rates in addition to they are often treated by carbapenems (e.g., ertapenem, imipenem, meropenem, and doripenem) (Legese et al., 2017). Recently, the efficacy of carbapenems has been threatened worldwide by the emergence of carbapenemresistant bacteria (Woodford et al., 2014) but to date no information is available about the occurrence of such problem in poultry which is an important source of protein produced in Egypt owing to their high feed-meat conversion and fast growth.

Carbapenems are broad-spectrum B-lactam antibiotics of critical importance in human medicine (Nordmann, 2014) and resistance of Enterobacteriaceae to carbapenems involves multiple mechanisms, the most remarkable of which is the production of enzymes called carbapenemases that are capable of hydrolyzing the carbapenems and loss of outer membrane proteins and the most remarkable of which are the big five enzymes KPC, NDM, IMP, VIM and OXA (Munoz-Price et al., 2013) KPC, OXA and NDM comprise three of the so-called 'big five' carbapenemases that have been associated with nosocomial infections (Cantón and Ruiz-Garbajosa, 2011).

The most of human enteric illness caused by bacterial pathogens originate from animals and can be transmitted directly from animals to humans or indirectly through foods of animal origin especially poultry derived items which are the main sources of infection by Salmonella spp. (Greig and Ravel, 2009). There are multiple links between human, animal and environmental compartments that allow not only the transfer of the bacteria, but also of mobile genetic elements and the drugs themselves (Woolhouse and Ward, 2013).

Therefore, this study was conducted to investigate the occurrence of ESBL and carbapenemase producing salmonellae in chicken meat, egg and human clinical samples suffering with diarrhea from different localities in Egypt.

\section{MATERIALS AND METHODS}

A total of 334 fresh chicken meat samples were collected from randomly selected poultry shops and 197 eggshells collected from poultry farms. In addition, 160 stool swab specimens selected from hospital lab suffering with diarrhea during the period from February to June 2018 in different localities in Egypt.

The Fresh chicken meat samples were transferred in boxes containing ice cubes and immediately processed in the laboratory for bacterial isolation where $25 \mathrm{~g}$ of the meat samples were obtained and processed with $225 \mathrm{ml}$ buffered peptone water (Singh et al., 2010).

A sterile cotton swab, soaked in sterilized normal saline, was swabbed on egg shell surface and immersed in $10 \mathrm{ml}$ normal saline solution followed by transmission to $90 \mathrm{ml}$ of buffered peptone water then incubated at $37^{\circ} \mathrm{C}$ for $18 \mathrm{~h}$ (Singh et al., 2010). For human stool samples: About 2 to $10 \mathrm{~g}$ stool was collected into a sterile leakproof container (without using any preservatives). The sterile cotton swab was coated thoroughly with the fecal material and then aseptically inoculated into tubes containing buffer peptone water.

For identification of Salmonella one $\mathrm{ml}$ of preenriched sample was added in $10 \mathrm{ml}$ Rappaport-Vassiliadis (RV) medium vortexed and incubated for $24 \pm 2 \mathrm{~h}$ at $42^{\circ} \mathrm{C}$, then loopfull of each RV tube was cultured onto the surface of XLD agar for $24 \mathrm{~h}$ at $37^{\circ} \mathrm{C}$. Typical Salmonella colonies were subjected to a series of biochemical, serological and molecular tests for identification of Salmonella spp.

Suspected colonies were identified by using chemical tests, including Gram staining, indole, methyl red, Voges Proskauer, citrate utilization, triple sugar iron and lysine decarboxylation (Atek et al., 2017).

Serotyping of isolates was performed in serogroup level with a standard agglutination test using $\mathrm{O}$ and $\mathrm{H}$ antisera (Difco, USA) in the central laboratories of the Ministry of Health, Giza, Egypt.

For molecular detection of carbapenemase and ESBL encoding genes, the DNA of Salmonella strains was extracted by using the conventional boiling method (Murugkar et al., 2003).

For multiplex PCR, specific oligonucleotide primers for ESBL encoding Genes (bla CTX-M, bla SHV and bla $T E M)$ and carbapenemase-encoding gene (KPC, OXA and NDM) (Table I).

The PCR reaction conditions consisted of initial denaturation cycle for $10 \mathrm{~min}$, followed by 35 amplification cycles for carbapenemase and ESBL encoding genes using the following conditions: Denaturation for $60 \mathrm{~s}$ at $95^{\circ} \mathrm{C}$, annealing for $60 \mathrm{~s}$ at $58{ }^{\circ} \mathrm{C}$, extension for $1 \mathrm{~min}$ at $72{ }^{\circ} \mathrm{C}$ and final extension for $10 \mathrm{~min}$ at $72{ }^{\circ} \mathrm{C}$.

\section{RESULT AND DISCUSSION}

A total of six isolates was isolated from 334 chicken meat and 197 eggshell surface samples (Table II). The serotyping of these isolates was $S$. Typhimurium (3), $S$. Enteritidis (2) S. Infantis (1) from chicken meat and one Salmonella isolates [S. Enteritidis] from eggshell surface samples. In addition, of 160 stool specimens collected from human, six Salmonella strains ( $S$. Typhimurium, $S$. Enteritidis, $S$. Infantis, $S$. Virchow, $S$. Haifa, $S$. Kentucky) were isolated. Among the total six strains of salmonella (Tables II, III) the overall prevalence of ESBL-producing salmonellae was four strains of chicken meat samples 
Table I. Primer sequences used for PCR amplification of ESBL and carbapenemase encoding genes.

\begin{tabular}{|c|c|c|c|}
\hline Target gene & Primer sequence $\left(5^{\prime}-3^{\prime}\right)$ & Amplified length (bp) & Reference \\
\hline blaCTX-M & $\begin{array}{l}\text { GCGATGGGCAGTACCAGTAA (F) } \\
\text { TTACCCAGCGTCAGATTCCG (R) }\end{array}$ & 392 & Hamza et al., 2020 \\
\hline blaSHV & $\begin{array}{l}\text { TCAGCGAAAAACACCTTG }(\mathrm{F}) \\
\text { TCCCGCAGATAAATCACCA }(\mathrm{R})\end{array}$ & 472 & Hamza et al., 2020 \\
\hline blaTEM & $\begin{array}{l}\text { ATGAGTATTCAACATTTCCG }(\mathrm{F}) \\
\text { TTACCAATGCTTAATCAGTGAG }(\mathrm{R})\end{array}$ & 861 & Hamza et al., 2020 \\
\hline KPC & $\begin{array}{l}\text { ATG TCA CTG TAT CGC CGT CT }(\mathrm{F}) \\
\text { TTT TCA GAG CCT TAC TGC CC (R) }\end{array}$ & 882 & (Li et al., 2012) \\
\hline OXA & $\begin{array}{l}\text { TTG GTG GCA TCG ATT ATC GG }(\mathrm{F}) \\
\text { GAG CAC TTC TTT TGT GAT GGC (R) }\end{array}$ & 743 & (Li et al., 2012) \\
\hline NDM & $\begin{array}{l}\text { GGT TTG GCG ATC TGG TTTTC (F) } \\
\text { CGG AAT GGC TCA TCA CGA TC (R) }\end{array}$ & 621 & (Li et al., 2012) \\
\hline
\end{tabular}

Table II. Serotyping of Salmonella strains and distribution of ESBL and carbapenemase producers and non producers.

\begin{tabular}{|c|c|c|c|c|c|c|}
\hline $\begin{array}{l}\text { Isolation } \\
\text { source }\end{array}$ & $\begin{array}{l}\text { Samples } \\
\text { (n) }\end{array}$ & Salmonella isolates & $\begin{array}{l}\text { ESBL- } \\
\text { producer }\end{array}$ & $\begin{array}{l}\text { Non- ESBL } \\
\text { producer }\end{array}$ & $\begin{array}{l}\text { CARB } \\
\text { producer }\end{array}$ & $\begin{array}{l}\text { Non-CARB } \\
\text { producer }\end{array}$ \\
\hline Chicken meat & 334 & $6 S$. Typhimurium(3), S. Enteritidis(1), S. Infantis(1) & 4 & 2 & 4 & 2 \\
\hline Egg & 197 & $1(S$. Enteritidis $)$ & 0 & 1 & 0 & 1 \\
\hline Human stool & 160 & $\begin{array}{l}\text { 6S. Typhimurium (1), S. Enteritidis (1), } S \text {. Infantis } \\
\text { (1), S. Virchow(1), S. Haifa (1), S. Kentucky (1) }\end{array}$ & 5 & 1 & 0 & 6 \\
\hline
\end{tabular}

Table III. Distribution of carbapenemase determinants, ESBL determinants genes in Salmonella strains.

\begin{tabular}{|c|c|c|c|c|c|c|c|c|}
\hline \multirow{3}{*}{$\begin{array}{l}\text { Salmonella } \\
\text { isolates (n) }\end{array}$} & \multicolumn{8}{|c|}{ Resistance genes } \\
\hline & \multicolumn{4}{|c|}{$\begin{array}{l}\text { Carbapenemase } \\
\text { determinants }\end{array}$} & \multicolumn{4}{|c|}{ ESBL determinants } \\
\hline & No. & NDM & OXA & KPC & No. & SHV & TEM & CTX \\
\hline $\begin{array}{l}\text { Chicken } \\
\text { meat (6) }\end{array}$ & 4 & 2 & 2 & 0 & 4 & 2 & 4 & 0 \\
\hline $\operatorname{Egg}(1)$ & 0 & 0 & 0 & 0 & 0 & 0 & 0 & 0 \\
\hline Human (6) & 0 & 0 & 0 & 0 & 5 & 5 & 0 & 3 \\
\hline
\end{tabular}

carrying $\beta$-lactamase-producing genes, 2 of which carried bla SHV and 4 carried bla TEM, while no strain in egg. This result agrees with (Pieskus et al., 2006) who mentioned that $S$. Enteritidis and $S$. Typhimurium were the dominant serotypes in both chickens and humans. The appearance of $S$. Enteritidis in human isolates was reflected by an increase in such serotype in chicken samples (van Duijkeren et al., 2002). S. Infantis is still of public health concern and it is the most commonly identified pathogenic serotype in the chickens, eggs and humans (Fearnley et al., 2011).

The carbapenem-resistant salmonellae were detected in four strains isolated from chicken meat samples; two carried the resistance genetic determinants bla ${ }_{N D M}$ and two carried bla oxA.

Among the total six Salmonella strains isolated from human (Tables II, III) five stains carried the $\beta$-lactamase producing genes where all of them were $b a_{C T X}$ and three strains carried $b l a_{S H V}$, while no strain was positive to carbapenemases. The inappropriate administration of antimicrobial agents in empiric therapies, lack of effective infection control strategies that could trigger a change in the prevalence of resistant organisms in the population, and selective pressure for the use of third-generation cephalosporins have been established as the most important factors in the emergence of ESBL-producing strains.

The genus Salmonella has recognized as the potential reservoir for different genes which encode antimicrobial resistance (Trudel et al., 2016). Although ESBL production by Salmonella spp. isolated from animals has been reported (Jiang et al., 2014), the reports on ESBL from animal origin are less frequent (Egervärn et al., 2014). The main driving force of resistance is the presence of $\beta$-lactamases (Bush, 2016). Moreover, many of these organisms carry additional plasmid-borne genes that are active against other antibiotic classes, thus making bacteria resistant to multiple drugs (Bush and Fisher, 2011). This result is in accordance to (Olesen et al., 2004) who reported that in Denmark the major recorded ESBL was the TEM group. However, (Djeffal et al., 2017) isolated two strain carried bla ${ }_{T E M}$ genes from poultry and no bla ${ }_{S H V}$ was detected in Algeria.

At the same time, four Carbapenem resistant Salmonellae were recorded. carbapenems are regarded as the drugs of choice for treatment of infections caused by ESBL-producing organisms. Unfortunately, the use of carbapenems has been associated with the emergence of 
carbapenem-resistant bacteria species such as salmonellae. Carbapenem-resistant Salmonellae determinants showed that two genotypes of $b l a_{N D M}$ and two genotypes of $b l a_{O X A}$ were carried on the isolated strains while no determinants are detected in the egg.

The result of ESBL and carbapenem resistance genes in human was revealed that among the total 6 Salmonella strains; 5 stains carried the $\beta$-lactamaseproducing genes, including 3 carried $b l a_{C T X}$ and 5 carried bla $_{S H V}$ while no strain positive to carbapenemase. Although in general antimicrobial treatment is not recommended for human salmonellosis, treatment can be necessary in cases of extraintestinal development of the illness, and immunologically compromised. Young and immunocompromised patients are the most susceptible to dangerous complications commonly treated with fluoroquinolones and extended-spectrum cephalosporins, which are widely used in veterinary medicine (Le Hello et al., 2011).

The most prevalent forms of ESBL in human are TEM, SHV, and CTX-M. The rates of CTX-M producing bacteria have increased worldwide compared to TEM and SHV over the last decade. This situation is made more complicated as these enzymes confer co-resistance to other drug classes. The bla ${ }_{C T X}$ gene and most antimicrobial resistance genes were found in a large conjugative plasmid. This plasmid has numerous genes that encode heavy metal ion resistance (Cantón and Coque, 2006). It is well known that the location of both metals and antibiotic resistance genes on the same mobile element plays a major role in the survival, selection and spread of antibiotic-resistant bacteria in anthropogenic environments heavily polluted with detergents, heavy metals and other antimicrobials (Laffite et al., 2016).

As well as, in developing countries, due to intense unregulated urbanization, rivers, lakes and lagoons are frequently polluted with untreated hospital and industrial effluents and often with urban storm-water containing anthropogenic contaminants. In addition, the release of antibiotics used in human and veterinary medicine into sewage and manure distribution systems can be associated with sewage sludge, contamination of rivers, liquid manure and farm soil (Tello et al., 2012).

\section{CONCLUSION}

The ESBL and carbapenem resistant genes can be transmitted from humans to animals, and from animals to humans through the food chain. Continuous surveillance of resistance to these "last resort" antibiotics is required to establish possible links between reservoirs and to limit the bidirectional transfer of the encoding genes.
Statement of conflict of interest

The authors have declared no conflict of interest.

\section{REFERENCE}

Atek, A.K., Andrew, B., Tonny, J.O., Joel, B., Samuel, M., 2017. Molecular characterization of Salmonella from human and animal origins in Uganda. Int. J. Bact., Article ID 4604789, pp. 9.

Bush, K., 2016. Top 10 beta-lactamase papers for 2015. Presented at: ASM Microbe 2016. Boston, MA, 18 June 2016. https://doi.org/10.1128/ microbe.10.208.1

Bush, K. and Fisher, J., 2011. Epidemiological expansion, structural studies, and clinical challenges of new $\beta$-lactamases from gram-negative bacteria. Annu. Rev. Microbiol., 65: 455-478. https://doi. org/10.1146/annurev-micro-090110-102911

Cantón, R. and Coque, T.M., 2006. The CTX-M betalactamase pandemic. Curr. Opin. Microbiol., 9: 466475. https://doi.org/10.1016/j.mib.2006.08.011

Cantón, R. and Ruiz-Garbajosa, P., 2011. Co-resistance: an opportunity for the bacteria and resistance genes. Curr. Opin. Pharmacol., 11: 477-485. https://doi. org/10.1016/j.coph.2011.07.007

Djeffal, S., Bakour, S., Mamache, B., Elgroud, R., Agabou, A., Chabou, S., Hireche, S., Bouaziz, O., Rahal, K. and Rolain, J.M., 2017. Prevalence and clonal relationship of ESBLproducing Salmonella strains from humans and poultry in northeastern Algeria. BMC Vet. Res., 13: 132-141. https://doi. org/10.1186/s12917-017-1050-3

Doi, Y., Iovleva, A. and Bonomo, R.A., 2017. The ecology of extended-spectrum $\beta$-lactamases (ESBLs) in the developed world. J. Travel Med., 1: 44-51. https://doi.org/10.1093/jtm/taw102

Egervärn, M., Börjesson, S. and Byfors, S., 2014. Escherichia coli with extended-spectrum betalactamases or transferable AmpC beta-lactamases and Salmonella on meat imported into Sweden. Int. J. Fd. Microbiol., 171: 8-14. https://doi. org/10.1016/j.ijfoodmicro.2013.11.005

Fearnley, E., Raupach, J., Lagala, F. and Cameron, S., 2011. Salmonella in chicken meat, eggs and humans; Adelaide, South Australia, 2008. Int. J. Fd. Microbiol., 146: 219-227. https://doi. org/10.1016/j.ijfoodmicro.2011.02.004

Greig, J.D. and Ravel, A., 2009. Analysis of foodborne outbreak data reported internationally for source attribution. Int. J. Fd. Microbiol., 130: 77-87. https://doi.org/10.1016/j.ijfoodmicro.2008.12.031

Hamza, D., Dorgham, S., Ismael, E., Ismail, S.A., 
Elhariri, M., Elhelw, R. and Hamza, E., 2020. Emergence of $\beta$-lactamase- and carbapenemaseproducing Enterobacteriaceae at integrated fish farms. Antimicrob. Resist. Infect. Contr., 9: 67. https://doi.org/10.1186/s13756-020-00736-3

Jacoby, G.A., Munoz-Price, L.S.N., 2005. The new beta-lactamases. N. Engl. J. Med., 352: 380-391. https://doi.org/10.1056/NEJMra041359

Jiang, H.X., Song, L. and Liu, J., 2014. Multiple transmissible genes encoding fluoroquinolone and third-generation cephalosporin resistance co-located in non typhoidal Salmonella isolated from food-producing animals in China. Int. J. Antimicrob. Agents, 43: 242-247. https://doi. org/10.1016/j.ijantimicag.2013.12.005

Laffite, A., Kilunga, P.I., Kayembe, J.M., Devarajan, N., Mulaji, C.K., Giuliani, G., Slaveykova, V.I. and Poté, J., 2016. Hospital effluents are one of several sources of metal, antibiotic resistance genes, and bacterial markers disseminated in SubSaharan urban rivers. Front Microbiol., 7: 1128. https://doi. org/10.3389/fmicb.2016.01128

Le Hello, S., Hendriksen, R.S., Doublet, B., Fisher, I., Nilsen, E.M. and Whichard, J.M., 2011. International spread of an epidemic population of Salmonella enterica serotype Kentucky ST198 resistant to ciprofloxacin. J. Infect. Dis., 204: 675684. https://doi.org/10.1093/infdis/jir409

Lee, J.Y. and Ko, K.S., 2012. OprD mutations and inactivation, expression of efflux pumps and AmpC, and metallo-_-lactamases in carbapenemresistant Pseudomonas aeruginosa isolates from South Korea. Int. J. Antimicrob. Agents, 40: 168-172. https://doi.org/10.1016/j.ijantimicag.2012.04.004

Legese, M.H., Weldearegay, G.M. and Asrat, D., 2017. Extended-spectrum beta-lactamase- and carbapenemase-producing Enterobacteriaceae among ethiopian children. Infect. Drug Resist., 10: 27-34. https://doi.org/10.2147/IDR.S127177

Logan, L.K. and Weinstein, R.A., 2017. The epidemiology of carbapenem-resistant Enterobacteriaceae: The impact and evolution of a global menace. Infect. Dis., 215(S1): S28-S36. https://doi.org/10.1093/infdis/jiw282

Majowicz, S.E., Musto, J., Scallan, E., Angulo, F.J., Kirk, M., O’Brien, S.J., Jones, T.F., Fazil, A. and Hoekstra, R.M., 2010. The global burden of nontyphoidal Salmonella gastroenteritis. Clin. Infect. Dis., 50: 882-889. https://doi. org/10.1086/650733

Miriagou, V., Tassios, P.T., Legakis, N.J., L.S. and Tzouvelekis, L.S., 2004. Expanded-spectrum cephalosporin resistance in non-typhoid Salmonella. Int. J. Antimicrob. Agents, 23: 547-555. https://doi. org/10.1016/j.ijantimicag.2004.03.006

Munoz-Price, L.S., Poirel, L., Bonomo, R.A., Schwaber, M.J., Daikos, G., Cornaglia, G., Garau, J., Gniadkowski, M., Hayden, M.K., Kumarasamy, K., Livermore, D.M., Maya, J.J., Nordmann, P., Pate, J.B., Paterson, D.L., Pitout, J., Villegas, M.V., Wang, H., Woodford, N. and Quinn, J.P., 2013. Clinical epidemiology of the global expansion of Klebsiella pneumoniae carbapenemases. Lancet Infect. Dis., 13: 785-796. https://doi.org/10.1016/ S1473-3099(13)70190-7

Murugkar, H.V., Rahman, H. and Dutta, P.K., 2003. Distribution of virulence genes in Salmonella serovars isolated from man and animals. Indian $J$. med. Res., 117: 66-70.

Nordmann, P., 2014. Carbapenemase-producing Enterobacteriaceae: Overview of a major public health challenge. Med. Mal. Infect., 44: 51-56. https://doi.org/10.1016/j.medmal.2013.11.007

Olesen, I., Hasman, H. and Aarestrup, F.M., 2004. Prevalence of beta-lactamases among ampicillinresistant Escherichia coli and Salmonella isolated from food animals in Denmark. Microb. Drug Resist., 10: 334-340. https://doi.org/10.1089/ mdr.2004.10.334

Paterson, D.L. and Bonomo, R.A., 2005. Extendedspectrum $\beta$-lactamases: A clinical update. Clin. Microbiol. Rev., 18: 657-686. https://doi. org/10.1128/CMR.18.4.657-686.2005

Pieskus, J., Milius, J., Michalskiene, I. and Zagrebneviene, G., 2006. The distribution of Salmonella serovars in chicken and humans in Lithuania. J. Vet. Med. Ser. A Physiol. Pathol. Clin. Med., 53: 12-16. https://doi.org/10.1111/j.14390442.2006.00789.x

Sanchez, S., Hofacre, C.L., Lee, M.D., Maurer, J.J. and Doyle, M.P., 2002. Animal sources of salmonellosis in humans. J. Am. Vet. med. Assoc., 221: 492-497. https://doi.org/10.2460/javma.2002.221.492

Singh, S., Yadav, A.S., Singh, S.M. and Bharti, P., 2010. Prevalence of Salmonella in chicken eggs collected from poultry farms and marketing channels and their antimicrobial resistance. $F d$. Res. Int., 43: 2027-2030. https://doi.org/10.1016/j. foodres.2010.06.001

Tello, A., Austin, B. and Telfer, T.C., 2012. Selective pressure of antibiotic pollution on bacteria of importance to public health. Environ. Hlth. Perspect., 120: 1100-1106. https://doi.org/10.1289/ ehp. 1104650 
Trudel, M.V., Vincent, A.T., Attéré, S.A., Labbé, M., Derome, N., Culley, A.I. and Charette, S.J., 2016. Diversity of antibiotic-resistance genes in Canadian isolates of Aeromonas salmonicida subsp. salmonicida: Dominance of pSN254b and discovery of pAsa8. Sci. Rep., 6: 35617. https://doi. org/10.1038/srep35617

van Duijkeren, E., Wannet, W.J.B., Houwers, D.J. and van Pelt, W., 2002. Serotype and phage type distribution of Salmonella strains isolated from humans, cattle, pigs, and chickens in The Netherlands from 1984 to 2001. J. clin. Microbiol., 40: 3980-3985. https://
doi.org/10.1128/JCM.40.11.3980-3985.2002

Woodford, N., Wareham, D.W., Guerra, B. and Teale, C., 2014. Carbapenemase-producing Enterobacteriaceae and non-Enterobacteriaceae from animals and the environment: an emerging public health risk of our own making? J. Antimicrob. Chemother., 69: 287-291. https://doi.org/10.1093/ jac/dkt392

Woolhouse, M.E. and Ward, M.J., 2013. Sources of antimicrobial resistance. Science, 341: 1460-1461. https://doi.org/10.1126/science.1243444 